\title{
Mirada escópica y vanguardia en la poética de Ana Clavel y de Mario Bellatin
}

\author{
Gaze and vanguard in Ana Clavel and \\ Mario Bellatin' poetry
}

\author{
Natalia Plaza Morales \\ Universidad París VIII \\ nplazamorales@hotmail.com
}

Recibido: 01-03-2015

Aceptado: 22-03-2016

\section{Resumen}

El presente trabajo tiene como objetivo analizar la literatura de Ana Clavel y de Mario Bellatin desde un enfoque estético. En estos dos escritores mexicanos contemporáneos, el procedimiento visual que se desprende del texto escrito, recupera, a través de la escritura, el valor que las vanguardias conferían a la mirada. Una propuesta narrativa que nos permite estrechar afinidades entre el universo narratológico de estos dos escritores.

Palabras clave: estética, imagen, campo escópico, vanguardia, transgresión.

\begin{abstract}
This paper aims to analyze Ana Clavel and Mario Bellatin literature from an aesthetic approach. In these contemporary Mexican writers, visual procedures in the written text recover the value that avant-garde movements conferred to gaze. Their narrative technique can be closer in these two writers.
\end{abstract}

Keywords: aesthetic, image, gaze, avant-garde, transgression. 


\section{Introducción: pasado y presente vanguardista}

Este trabajo surge del estudio de las obras de los escritores mexicanos Ana Clavel y Mario Bellatin, y nos conducirá a relacionar una serie de similitudes estéticas en las expresiones literarias de ambos autores. Observamos dos ejes fundamentales en sus creaciones:

1) Ambos autores conciben la literatura como algo que necesita de otros dominios artísticos para gestarse.

2) La transgresión en estos autores podría sugerir nuevas dimensiones estéticas a través de la mirada psicoanalítica.

Hoy en día se habla mucho de literatura de la transgresión, un dominio bastante amplio que abarca una cantidad considerable de autores con temáticas diferentes, quienes se vinculan por compartir una escritura que desafía los parámetros normativos.

Nuestro análisis pretende demostrar que en la narrativa de Ana Clavel y de Mario Bellatin (así como de otros autores contemporáneos que no podrán ser analizados aquí) se revela un proceso estético que se desmarca de otros escritores de la transgresión y que, creemos, está en relación directa con un ámbito fundamental del psicoanálisis: el campo escópico. Recordemos que, para Lacan, solo la pulsión puede engendrar esta estética de la transgresión en el sujeto pulsional: "El camino de la pulsión es el único camino de la transgresión que se le permite al sujeto con respecto a la pulsión"1.

Veremos pues, cómo en estos autores, la puesta en marcha de una escritura más visual se consigue, entre otros artificios, gracias al valor simbólico de la mirada. Este nuevo estilo ${ }^{2}$ se está forjando desde la estética. Tal "forma" narrativa se esclarece por la contemporaneidad de las creaciones que nos ocupan: un paradigma social y cultural que es producto de la sociedad mediática, de la preferencia por lo visual.

Es obvio que tanto Ana Clavel como Mario Bellatin incluyen en sus relatos una serie de referentes de ficción que nos remiten a la vanguardia artística de los años 1920-30. En los dos autores mexicanos encontramos, de una manera u otra, la huella de Duchamp y de la vanguardia surrealista. No son los únicos. Otros escritores latinoamericanos han recuperado y renovado la tendencia vanguardista. Para Cesar Aira, la renovación de la vanguardia debe ser comprendida como una opción, una

\footnotetext{
${ }^{1}$ Lacan, J., Les quatre concepts fondamentaux de la psychanalyse, Le Séminaire, Livre XI, Paris, Ed du Seuil, 1973, p.205.

2 Tomaremos la definición de estilo de Arthur C. Danto en su obra Después del fin del arte, Barcelona, Paidós Ibérica, 1997, p.35: "un estilo es un conjunto de propiedades que comparten un corpus de obras de arte, pero que está lejos de poder ser tomado para definir, filosóficamente que son obras de arte".
} 
alternativa para reinventar arte. De acuerdo con el escritor argentino, es el procedimiento lo que distingue el arte de lo que no lo es, de lo que sólo es lenguaje. Y es este procedimiento narrativo el que nos permitirá encontrar una raíz común entre una generación presente de escritores:

Cuando una civilización envejece, la alternativa es seguir haciendo obras, o volver a inventar el arte. Pero la medida del envejecimiento de una civilización la da la cantidad de invenciones ya hechas y explotadas. Entonces esta segunda alternativa se va haciendo más y más difícil, más costosa y menos gratificante. Salvo que se tome el atajo, que siempre parecerá un poco irresponsable o bárbaro, de recurrir al procedimiento. $\mathrm{Y}$ eso es lo que hicieron las vanguardias. ${ }^{3}$

En este sentido, como lo afirma Julio Premat, al referirnos a la literatura y a su esencia vanguardista, tenemos que pensar en que ese dialogar con la vanguardia histórica no tiene por qué ser pensado en tanto que regreso a la tradición, tampoco como una progresión o continuación, tal y como algunos se empeñan en querer relacionar:

En realidad, la primera impresión, cuando se habla de vanguardias, es que la linealidad temporal inherente a su etimología y a sus primeras peripecias se aplica, ante todo, a los juicios sobre ella: la vanguardia ya pasó, ya está hecha, ya terminó, fue necesario hacer lo que hizo y se cumplió con ello, fue necesario y no se cumplió .Los relatos de la vanguardia o el retorno de lo nuevo con ello, los vanguardistas de los veinte o los de los sesenta fracasaron, triunfaron, hay que ir más lejos, hay que ir en otra dirección, es ingenuo pensar que vamos a alguna parte, el arte no va, es decir, no progresa, etc. Entonces, ¿cómo inscribir a la vanguardia en lo contemporáneo? ¿Cómo pensar su tiempo, lo contemporáneo? 4

Si concebimos la relación que la literatura contemporánea mantiene con la vanguardia desde la historicidad del escritor y de su creación, descubrimos que existe una nueva literatura con grandes preocupaciones estéticas que, sin recuperar los valores éticos-morales de estos movimientos, es decir, sin echar una mirada concienzuda hacia las tendencias artísticas del pasado ni confrontarse a ellas (recordemos que André Bretón en El primer manifiesto surrealista (1924) invitaba a prescindir de toda norma estética, a huir de toda lógica y preocupación moral) sigue manteniendo un diálogo continuo con una tradición histórica vanguardista. Comprendemos esta literatura contemporánea como un proceso dinámico que se

\footnotetext{
3 Aira, C., «La nueva escritura», Centro de Estudios de Teoría y Crítica, 8, (2000), Rosario, Universidad Nacional de Rosario, pp. 165-170.

4 Premat, J., «Los relatos de vanguardia o el retorno de lo nuevo», Cuadernos de literatura, (2013), Bogotá, Pontificia Universidad Javeriana, pp.52-53.
} 
reinventa. Creemos que esta "manera" de narrar que utilizan autores como Mario Bellatin y Ana Clavel, da paso a nuevas formas de lo fantástico que estimulan la imaginación gracias a la impresión que nos producen el cuerpo y la mirada como espacios del imaginario. Un efecto visual que no recurre solamente a la imagen, sino a cualquier elemento que puede plantear un juego de dimensiones entre el texto y el espectador. Podríamos pensar que estos escritores de lo contemporáneo están construyendo una tendencia estética en literatura (buscada o no), bajo la herencia de ciertos movimientos de vanguardia, que marca, en cierto sentido, una tendencia estética heteróclita:

Reprocesar residuos, materias, más allá de los gustos y de las tramposas recetas del "escribir bien": la práctica literaria, así desembarazada de lo aparente, sería, por fin, alimenticia. La vanguardia, entonces, es lo que resiste, la médula del arte. En todo caso, nombrar de otra manera, definir los términos de otra manera, implicaría pensar de otra manera al autor y al texto. 5

\section{Mirada escópica, cuerpo y transgresión}

Recordemos que los surrealistas, influidos por el psicoanálisis freudiano 6 , incidieron en el valor de la mirada, elevando la pulsión escópica al mismo nivel que la fantasía y el sueño. Así, Dalí plasmaba el espacio simbólico de la percepción visual dibujando ojos en sus pinturas, confiriendo un rol fundamental al acto de mirar más allá de sus características sensitivas. Esta simbolización de la mirada debía ser entendida como algo que se eleva desde la percepción (el acto de ver) hasta el dominio del inconsciente como forma de conocimiento y de sublimación. En Ana Clavel y Mario Bellatin, la mirada es concebida como un espacio simbólico de representación que explota un discurso de lo visual a modo delirante y obsesivo. La mirada se convierte en un proceso subjetivo, un juego estético con el cuerpo, canal erótico de la experiencia interior. Ambos escritores recurren a los mecanismos del psicoanálisis para exaltar los estados de angustia y de ausencia en el monólogo de sus narradores-protagonistas?.

Observamos en ambos escritores afinidades que podemos relacionar con procesos artísticos utilizados por el cine y la fotografía. Podríamos pensar que la literatura de estos autores estrecha las fronteras con otros géneros por medio del mecanismo narrativo de la mirada en algunos de sus relatos:

\footnotetext{
5 Premat 2013, op. cit (nota 4), p.52.

6 Recordemos que en su ensayo "Au delà du principe de plaisir" Freud había sugerido que el ojo era el órgano fundamental, causa de placer y de dolor en el hombre.

7 Cfr. Diccionario en línea de Mario Bellatin. (próximamente en Cuadernos líricos).
} 
Casi derrotado alzó la mirada hacia los cielos. Tal vez arrepentido, iba a clamar perdón a los dioses. Pero entonces descubrió en la punta de la rama una nueva fruta temblorosa, apetecible, que crecía suculenta pero imposible para él .Y debió maldecir en injurias a los dioses cuando comprendió que con el simple acto de mirar el tormento se reavivaba ferozmente en su entraña. ${ }^{8}$

Con este propósito, es interesante referirnos a las teorizaciones de Benjamin Walter, en lo que respecta al campo de la imagen. Así, en "La obra de arte en la época de su reproductibilidad técnica" (1936), el filósofo analiza la imagen fotográfica y cinematográfica. Benjamin Walter formula cómo los procedimientos cinematográficos han contribuido a facilitar una óptica visual que ya había sido preconizada por Freud y el psicoanálisis:

Del mismo modo se puede apreciar que el mundo natural que se dirige a la cámara no es igual al que se presenta ante la mirada ; es particularmente diferente a causa de que, en vez de un espacio dispuesto por el sujeto mediante su consciencia, ofrece otro inconsciente establecido (...) Es en este punto preciso que acciona la cámara con sus recursos de ayuda, sus ascensos y descensos, sus montajes y su idoneidad para aislar, dilatar y retardar el curso de algo, su competencia para ampliar y también reducir según diversas escalas. Sus cualidades hacen que percibamos el inconsciente según la óptica, de modo similar a como, a través del método psicoanalítico, aprendemos sobre el inconsciente de origen pulsional. ${ }^{9}$

Creemos que la mirada es un mecanismo fundamental en la narrativa de estos dos escritores, ya que sirve para dar fuerza a la dialéctica del deseo que encontramos en sus relatos. Para entender el juego estético que ofrecen sus ficciones, tenemos que acudir a la teoría psicoanalítica y observar cómo la escritura de estos autores se inscribe en un fluir continuo de una acción narrativa: la pulsión escópica como efecto visual de performance10.

Para Freud, el sueño era la realización de un deseo. Partiendo de esta fórmula, podemos afirmar que ambos escritores buscan crear en sus historias una atmósfera de deseo incompleto e irrealizado a través de sus narradores-protagonistas. El sueño no puede ser el único medio, puesto que nos llevaría a la realización de la pulsión. Para el desarrollo de sus ficciones, ambos escritores se valen de un narrar que oscila entre la representación onírica y el principio de la realidad ficcional. Una narración que, diríamos, busca una relación entre el deseo y la ausencia: "Yo estaba convencido de que mis genitales debían darle a mi madre todo el tiempo algún tipo de satisfacción"11.

\footnotetext{
8 Clavel, A., Las Violetas son las flores del deseo, Mexico, Alfaguara, 2007, p. 15.

9 Walter, B., Textos esenciales, Buenos Aires, Ediciones Lea S.A., 2014, p. 72.

10 Para Freud, la pulsión sería una energía corporal que satisface momentáneamente una ausencia.

${ }^{11}$ Bellatin, M., El Gran Vidrio, México, Editorial Alfaguara, 2007, p. 52.
} 
Ese narrar del deseo tiene como elemento la mirada, y nos lleva, por medio del fantasma a dimensiones diferentes:

Para los antiguos, el phantasma era el puente entre el alma, prisionera del cuerpo y el mundo interior. La poesía y el arte dejan escapar, transfigurado al prisionero: al deseo, a la imaginación enterrada desde el primer día por las instituciones y las prohibiciones. 12

Recordemos que en términos psicoanalíticos, la mirada distingue la función del ojo (la vista) del acto de mirar. La diferencia entre el mirar y el ver es lo que nos permite hablar de pulsión escópica en términos lacanianos:

La esquicia entre mirada y visión nos permitirá, como verán, añadir la pulsión escópica a la lista de pulsiones. Si uno sabe leerlo, se da cuenta de que Freud la coloca ya en primer plano en las pulsiones y sus destinos, y muestra que no es homóloga a las otras. En efecto, ella es la que elude más completamente el sentimiento de la castración. ${ }^{13}$

El deseo de contemplar es una necesidad en el ser humano, sostiene Lacan, de ahí el valor de la mirada. La obra de arte nos ofrece ese espectáculo en el que podemos contemplar el deseo del Otro, el cual produciría en el ser humano una forma de sosiego, de relajación frente a la irrealización de su propio deseo. Para Lacan, la ilusión óptica o trompe l'oeil, nos lleva a percibir una realidad distinta, fantasmagoría. Tal sensación es la que se desprende de algunas escrituras de Ana Clavel y de Mario Bellatin en su sentido estético con la mirada. Ese gesto del lenguaje, que nos permite figurar el deseo desde la imagen, no necesita un objeto concreto, éste carece de importancia como lo señalaba Freud. En el caso de Bellatin, su narrativa en $E l$ gran vidrio (2007) presenta dos objetos de pulsión: el órgano genital masculino del personaje y su relación con la pulsión oral (la boca de la madre): "No podía permitir que la boca de mi madre fuera más importante que el espectáculo que mis testículos podían ofrecer"14. En la narrativa de Ana Clavel, el ojo actúa como objeto de la pulsión en sí mismo: "La violación comienza con la mirada, cualquiera que se haya asomado al pozo de sus secretos lo sabe"15. En Las Violetas son las flores del deseo (2007), la pulsión escópica construye una dialéctica de la mirada que sitúa al lector como partícipe de la historia que contempla. Así, éste se sitúa en un rol de voyerista como perverso, está ahí, frente al texto, en su acción, no de ver, sino de mirar:

\footnotetext{
12 Paz, O., La llama doble: Amor y Erotismo (1993), Barcelona, Editorial Seix Barral, 2014, p.179.

13 Lacan 1964, op. cit. (nota 1) p. 91.

14 Bellatin 2007, op. cit. (nota 11) p. 12. Confróntese el diccionario del Gran Vidrio de Mario Bellatin, próximamente en línea en Cuadernos Lírico, y la entrada Mirada de El gran vidrio (2007) de Bellatin. 15 Clavel 2007, op. cit. (nota 8) p. 5.
} 
Para que dos se condenen basta una mirada. Para que se reconozcan y se palpen, para que sepan santo y seña, para que dialoguen, acallen vociferen en el idioma sin palabras del pecado. Una mirada sola. No hace falta más. Para perderse y ¿Por qué no reconocerlo de una vez? También para salvarse irrevocablemente. 16

Según Lacan, para que exista la pulsión escópica, tiene que existir este proceso de voyerismo, una relación con el Otro que nos haga imaginarnos como parte de esa mirada que el deseo transporta sobre nosotros:

Y eso es cierto especialmente del materialista, al nivel escópico, ya no estamos al nivel de la demanda, sino del deseo, del deseo del Otro. Lo mismo ocurre al nivel de la pulsión invocadora, que es la más cercana a la experiencia del inconsciente (...) En general, la relación con la mirada y con lo que se quiere ver es una relación de señuelo, El sujeto se presenta como otro que no es, y lo que se le da a ver no es lo que quiere ver. Por eso el ojo puede funcionar como objeto, es decir, a nivel de carencia. ${ }^{17}$

Es decir, para que se reflejen, se perciban una serie de estados como el pudor, la vergüenza, la confesión...necesitamos proyectarnos en el campo de visión del Otro:

La mirada es este objeto perdido, y de repente reencontrado, en la conflagración con la vergüenza, por la introducción del otro. Hasta aquí, ¿qué intenta ver el sujeto? Intenta ver, sépanlo ya, es el objeto en tanto ausencia, Lo que el voyeur busca y encuentra no es más que una sombra, una sombra detrás de la cortina. 18

De tal forma que, mi mirada es un narrar para/con el Otro. El objeto de la pulsión pierde importancia, valor, diríamos, con respecto al sujeto pulsional, que se convierte en objeto del Otro. Ese sujeto de la pulsión es también el lector, voyerista de un discurso con la mirada y partícipe del deseo:

Estoy por fin en el bosque. Huele a humedad pero también a una fragancia dulce y silvestre. Me adentro como si supiera que debo llegar a un destino. Cruzo barrancos y riachuelos, también parajes espinosos y agrestes. Cuando me creo perdido, alcanzo a divisar un árbol de tronco enhiesto y vigoroso. Me aproximo y descubro que tiene un hueco del tamaño de mi rostro. Pero el hueco no está vacío. En su interior hay un panal. [...] Hundo un dedo en la corriente que baña ya la corteza del árbol y percibo un estremecimiento en la cera que comienza a cuajarse y rápidamente forma el cuerpo de una muchacha parecida a Susana Garmendia. Está unida al árbol como si la hubieran atado con este propósito. Se halla completamente a mi merced. ${ }^{19}$

\footnotetext{
16 Ibidem, p. 67.

17 Lacan 1964, op.cit. (nota 1) p. 98.

18 Ibidem, p. 204.

19 Clavel 2007, op. cit. (nota 8) p. 108.
} 
Ese "mirar a través de la cerradura" del que nos hablaba Lacan, es la función que adquiere el lector como voyeur. El terrero de la mirada estará ligado a una dialéctica del deseo:

En el momento en que él mismo se ha presentado en la acción de mirar por el aguajero de cerrado. Una mirada le sorprende en la función de voyeur, le desconcierta, le trastorna, y lo reduce a la sensación de vergüenza. La mirada en cuestión es presencia de otro como tal. Pero ¿qué significa eso que originalmente es en relación de sujeto a sujeto, en la función de la existencia de otro en cuanto que me mira, que comprendemos eso de lo que se trata en la mirada? ¿No está claro que la mirada sólo interviene aquí en tanto que no es el sujeto nidificarte, correlativo al mundo de la objetividad quien se siente ahí sorprendido, sino que el sujeto que se mantiene en esa función del deseo? ¿No es precisamente porque el deseo se instaura aquí en el campo de la visura, por lo que podemos escamotearlo?20

Si hablamos del erotismo que se desprende de la acción de mirar en estos dos escritores mexicanos, lo concebiríamos como algo que transgrede las normas, las reinvierte, pero también es un procedimiento poético que se entrelaza con la mirada. El erotismo se conjuga con la violencia, con la sugestión y con la sensualidad. En el caso de Mario Bellatin, dicha sensación narrada se centra a menudo en las pulsiones de muerte, mientras que en Ana Clavel, el instinto de conservación sale a flote en lo que concierne la pulsión en el narrador-protagonista de Las Violetas son las flores del deseo (2007):

Mientras Violeta subía a su recámara y nos dejaba solos, era extraño aguardar junto a ellas, a las que conocía desde antes de su nacimiento en los moldes, de quienes en cierta medida era yo su progenitor, y presenciar ahora su naturaleza inquietante y silenciosa. Sentadas a mi alrededor, los brazos y las piernas abiertos no sé si reclamando una suerte de abrazo total o encarnando un estado de gracia fulminante y dispuesto, eran también pequeñas esfinges del destino cuyos labios inmóviles parecían susurrar: "Sabemos mucho mejor que tú mismo lo que estás pensando detrás...21

El erotismo puede percibirse como una emoción que denota placer o, en tanto que una sensibilidad estética que puede surgir a partir de emociones contrarias como el miedo, lo extraño y lo desconocido. La mayoría de los teóricos del erotismo (Paz, Bataille...) van a considerar esta manifestación como algo que viola las normas, las reinvierte y las transgrede. Para Octavio Paz, el límite entre lo sexual y lo sensual se encuentra en el poder evocador. La percepción no se limitaría a "ver", sino que el erotismo debe activar el imaginario:

\footnotetext{
20 Lacan 1964, op.cit. (nota 1) p. 98.

21 Clavel 2007, op. cit. (nota 8) p.74.
} 
La poesía traza un puente entre el ver y el creer (...) por este puente la imaginación cobra cuerpo y los cuerpos se vuelven imágenes. La relación entre erotismo y poesía es tal que puede decirse sin afectación que el primero es una poética corporal y que el segundo es una erótica verbal. Ambos estarían constituidos por una oposición complementaria. El lenguaje-sonido que emite sentidos, trazo material que denota ideas incorpóreas- es capaz de dar nombre a lo más fugitivo y evanescente: la sensación; a su vez, el erotismo no es mera sexualidad animal: es ceremonia, representación. El erotismo es sexualidad transfigurada: metáfora. ${ }^{22}$

Para ciertos autores como María Mercedes Gómez, el erotismo no tiene como único objetivo la excitación sexual, es más bien, diríamos, un descubrimiento o redescubrimiento de sensaciones que no son únicamente sexuales, pero se leen como una exploración del cuerpo ${ }^{23}$. Por ejemplo, la performance video de Cuerpo Náufrago (2005) de Ana Clavel podría leerse como una puesta en escena que formula cuerpos eróticos con sexualidades y comportamientos inconclusos, ambiguos e indeterminados, una imagen visual que sugiere más que dice sobre la sexualidad y el cuerpo de deseo mismo. ${ }^{24}$

Observemos, por ejemplo, cómo Ana Clavel describe una escena de violación transfigurada por el recurso de la metonimia. La poética erótica utilizada por la autora está libre de significaciones, se presta a la ambigüedad, y puede tener múltiples connotaciones: "Niñas violentadas con el vientre despanzurrado como muñecas inservibles. Olas pubescentes que se habían quedado atoradas en las miasmas de dolor y ultraje" 25 .

Para Bataille, la literatura no puede transmitir ni los estados extremos ni aquellos de éxtasis. La comunicación verbal nos lleva a la "vulgaridad". La literatura es "vulgar", puesto que sigue comprometiéndonos con las convenciones adquiridas. Para expresar la angustia, debe existir un deseo de comunicar este estado que nos perturba. El habla pone fin a este deseo, puesto que pasamos del miedo a la constatación y a la realización de la pulsión mediante el lenguaje:

El punto extremo está en otro sitio. No es alcanzado por completo hasta ser comunicado (el hombre es vario, la soledad, el vacio, la nulidad, la mentira). Que una expresión cualquiera dé testimonio de él: el extremo es distinto de ella. Nunca es literatura. ${ }^{26}$

\footnotetext{
22 Paz 2013, op.cit. (nota 12) p.13.

23 En Derecho y Pornografía. Catherine A. MacKinnon Richard Posner, Bogotá: Siglo del Hombre / Editores/ Universidad de los Andes, 1997: http://manzanadiscordia.univalle.edu.co2 María Mercedes Gómez, «La mirada pornográfica». Introducción. En: Derecho y pornografía. Catherine A. MacKinnon,Richard Posner. Bogotá: Siglo del Hombre Editores/Universidad de los Andes, 1997, p.13:/volumenes/articulos/A1N2/art4.pdf

${ }^{24}$ Performance Cuerpo Náufrago. Disponible en : https://www.youtube.com/watch?v=a7ZJRmgLyFI

25 Clavel, A., Las ninfas a veces sonrien, México, Editorial Alfaguara, 2013, p.5.

26 Bataille, G., L'expérience intérieure (1943), Paris, Ed. Gallimard, 2005, p. 64.
} 
En este sentido, podríamos decir que, recurrir a mecanismos que favorecen el contemplar estético, hace que la escritura de Mario Bellatin y de Ana Clavel, a pesar de sus intenciones transgresivas, trascienda el registro narrativo. Se crean pues cuatro dimensiones: el espacio lingüístico-textual, la propuesta visual representada como acción o efecto en movimiento gracias a la performance, los mecanismos del imaginario, los cuales ofrecen al lector otras posibilidades más allá del texto, y una cuarta dimensión que corresponde al lector mismo, en tanto que éste se encuentra en una posición de voyerista, en una perspectiva privilegiada para ser partícipe de los acontecimientos. Es esta forma de transgresión la que se nos presenta a nivel estético y la cual el lector descodifica según sus propias percepciones. Recordemos las palabras de Octavio Paz con respecto al erotismo y a la relación que mantiene con la mirada y la acción voyerista en la obra pictórica:

El erotismo es la condición de la videncia. Además de ser conocimiento, la visión erótica es creación. Nuestra mirada cambia el objeto erótico: lo que vemos es la imagen de nuestro deseo. Son los mirones los que hacen el cuadro 27.

En una entrevista con Mario Bellatin, a la pregunta de un periodista acerca de su mundo narratológico (considerado por la crítica como extraño y singular), el escritor ofrece una respuesta contundente: Bellatin no piensa que su escritura sea un universo único, sino que es un mundo compartido por otros escritores de lo contemporáneo. Cierto, puede que el escritor mexicano sea mucho más extremo en su procedimiento estético pero, en realidad, su espacio narrativo es paralelo al de la escritora de Las Violetas son las flores del deseo:

Periodista: Sus historias se desarrollan en una especie de extraña realidad paralela, ¿No le asusta el mundo que ha creado?

Bellatin: Creo que se trata de un mundo real y contemporáneo. Que no me pertenece en exclusiva. Lo que quizá despierte cierta extrañeza es que los elementos literarios no aparecen de manera convencional. 28

La recurrencia a la performance visual, que confiere a la imagen una importancia fundamental, se refleja en toda la obra de Mario Bellatin. En Canon Perpetuo (1993), el efecto visual de la descomposición del cuerpo se nos presenta como un gesto prolongando que combina lo carnal con lo psíquico (la angustia de muerte) y con la trasmutación. El cuerpo es el canal que muda, que se reconvierte o se descompone. A través de la mirada, el mundo físico se desintegra, pierde sus propiedades: como si estuviésemos desdibujando la facultad de ver claro y tuviésemos que

27 Paz 2013, op.cit. (nota 12) p. 283.

28 Entrevista con Mario Bellatin en el diario El pais : http://elpais.com/diario/2007/06/09/babelia/1181346616_850215.html 
imaginar, olvidar lo que la vista y la percepción nos ofrecen y que conocemos tan bien, en tanto que se conforman como imágenes ya procesadas en nuestra memoria.

Entonces, en Bellatin, la imagen del cuerpo se difumina a través del lenguaje y de la mirada, con la violencia de quien ya no puede ver con claridad y necesita recrear con la palabra lo que su ojo ya no percibe. Se construye una narrativa que parece perseguir la consecución de un efecto visual de trance, de pérdida de toda consciencia de visión, gracias a la descripción de la desfiguración de imágenes:

Los objetos, como antes los olores, comenzaron a confundirse unos con otros. Perdieron sus límites. La silla de Viera y los frascos de medicina. Se fusionaron la sábana y el cuerpo enfermo, la cama y la palangana de fierro enlozado que se mantenían en un rincón. 29

Nos parece que Bellatin crea, gracias a este efecto pictórico del lenguaje, una sensación en proceso, en movimiento, que oscila entre el estado moribundo del ser y el cuerpo agonizante, focalizándose en ese instante en el las imágenes pierden forma y color, creando un efecto de retina muy real y visual en el espectador. Las imágenes se desdibujan para entrar en el instante de pérdida de memoria y de visión del cuerpo cercano a la muerte: "El rostro y las manos se confundirían con el blanco de la sábana." 30

Esta performance visual es una constante en la narrativa del escritor mexicano, siempre como una imagen en progreso, una representación visual que procesa la contemplación del cuerpo deteriorado por el tiempo o por la malformación. Lo visual sirve para crear una sensación de dolor y de angustia que no tiene por qué percibirse como psíquica (por carencia o falta de alguien) sino que sobretodo es un dolor físico, de mutilación.

En Efecto invernadero (1992), percibimos el recurso del espejo como un artificio más de la performance visual. El efecto del ver/ser parece asociar la belleza, no a un canon estético convencional, sino al efecto de estar vivo:

Al levantarse en las mañanas, Antonio se quedaba una hora más delante de su propia figura. Iba examinando con paciencia el aumento de la turbidez en los ojos, así como la carne del cuello y las piernas (...) Antonio dijo cierta vez que la belleza y la muerte guardaban en si la misma relación que el agua con los espejos. ${ }^{31}$

Esta dialéctica del cuerpo nos reenvía, por un lado, a la vida, a través del artificio que produce el reflejo del agua, por otro, a la muerte, recreada como espacio sin imágenes, insípido por su ausencia.

\footnotetext{
29 Bellatin, M., Efecto invernadero, México, Editorial Alfaguara, 1992, p.43.

30 Ibidem, p.41.

31 Bellatin 1992, op.cit. (nota 28) p. 61.
} 
En Canon perpetuo (1993), el espejo es de nuevo un recurso que parece construir un reflejo de la imagen corporal que se nos presenta en un estado de disociación permanente ante el paso del tiempo. De nuevo, el cuerpo deteriorado en Bellatin es el mecanismo de un dolor en proceso: "Ya era tiempo de convivir con naturalidad con un físico en continuo deterioro" 32

Recordemos que Merleau-Ponty acordaba al espejo esa facultad de hacer espectáculo, de permitir el juego entre el imaginario y lo real:

En cuanto al espejo, es el instrumento de una magia universal que transforma las cosas en espectáculos, y los espectáculos en cosas, que me transforma a mí en el otro y al otro en mí. 33

Tanto Ana Clavel como Bellatin recurren al efecto-imagen para reconstruir la narrativa del cuerpo como una performance, una interacción entre la imagen y la palabra, pero lo hacen con intenciones distintas: el cuerpo en Ana Clavel es una poética del deseo, mientras que en Bellatin, dicha figuración es simbolización del sufrimiento físico y de la imperfección. La representación del cuerpo enfermo, malformado, se convierte en una imagen visual y escrita prolongada, un dolor sin fin. El cuerpo en el escritor mexicano es siempre una representación carnal de dolor: cuerpos cancerígenos, niños mutilados, escritores de ficción con malformaciones, como es el caso del personaje de Shiki Nagaoka, caracterizado por poseer una enorme nariz que provoca rechazo e incomprensión.

La mirada adquiere una importancia fundamental en el dominio de la estética porque nos produce un efecto contrario al esperado. Tales descripciones no nos conducen a apartar la mirada, sino que nos invitan a reformularla, a concebirla, a reeducarla diríamos.

Existe pues, en la literatura Ana Clavel un deseo sin consecuencias, sin realización, que se condensa en la mirada erótica como dialéctica entre el sujeto que mira y el que se siente observado. El objeto de deseo deja de ser una mera contemplación visual y se abren interrogantes acerca del juego de mirar y de la percepción, se formulan posibilidades sugestivas contradictorias entre el lenguaje escrito y la imagen denotativa:

Me había convertido, que duda cabía, en una muñeca inerte. Mi visitante no tuvo piedad: subió a la cama y mi corazón dejó de rebotar y por unos instantes me abrió de piernas y me obligó a recibir su deseo frontal como un sublime estado de gracia. ${ }^{34}$

\footnotetext{
32 Bellatin, M., Canon Perpetuo, México, Editorial Alfaguara, 1993, p.71.

33 Ibidem p.31.

34 Clavel 2007, op. cit. (nota 8) p.108.
} 
Decía Merleau Ponty que "solo se ve aquello que se mira", que no basta con pensar para ver: "la visión es un pensamiento condicionado, nace "con ocasión" de lo que acaece al cuerpo, es "excitada" a pensar en el cuerpo. De esta forma, la mirada, como proceso abierto, se convierte en una estrategia narrativa que entremezcla realidades opuestas entre el lenguaje inculpatorio del personaje en Las Violetas son las flores del deseo (2007) y el "efecto voyerista" del relato, que invita a una realidad fantasiosa transgresiva. Corresponde al lector de imaginar, crear un discurso que no está condicionado únicamente por el texto escrito.

$\mathrm{Al}$ interpretar algunos de los pasajes de la narrativa de Mario Bellatin, podríamos decir que el rechazo del cuerpo se produce en el individuo con malformaciones a partir del repudio del Otro. Adjetivos como "carne muerta", "decapitación, "desquebramiento", dan cuenta de algo que se percibe desde proporciones como el asco o lo anti-estético que producen en la mirada ajena. En los relatos del escritor mexicano, el cuerpo protésico, defectuoso, malformado, nos reenvía a la mirada externa y a la manera en qué ese cuerpo causa un dolor incrementado, porque coexiste con otras miradas que lo determinan como extraño. Así, el dolor no solo es físico sino también es producto del contraste con la mirada del Otro: "Colócate el brazo, quítate el brazo ¿Dónde has puesto el brazo? No asustes a los niños con el brazo" 35 .

Cuando confrontamos la mirada a lo protésico, a lo antiestético, estamos desnaturalizado su representación convencional. Ana Clavel también incide en la ruptura de la dicotomía natural/artificial, al desdibujar estas nociones a través del cuerpo erótico artificial de las muñecas en su relato Las Violetas son las flores del deseo (2007). Este mismo proceso es el que consigue Mario Bellatin con las malformaciones, los miembros artificiales. Estos escritores trabajan la trasgresión a través del cuerpo desde la combinación del binarismo tradicional natural/artificial como polos no opuestos. El resultado (aunque pueda resultar extraño) nos parece positivo, porque ambos escritores consiguen familiarizar ciertos conceptos y nociones opuestas a la mirada social y a la estética convencional.

Los mecanismos de Ana Clavel y de Mario Bellatin son un espectáculo semántico y artístico de opuestos y contradicciones que, podríamos formular, se reúnen en un solo gesto de escritura, en una misma imagen predicativa:

Violeta, que me había visto blandirme como una navaja antes de quebrarse por la mitad, se me acercó, me tomó del brazo y pidió ayuda a su tía Isabel. Ambas me condujeron a la casa. Seguramente fue Isabel la que llamó al médico que se encargó de inyectarme el tranquilizante adecuado: debía dormir y, aunque fuera fugazmente, olvidar. Comencé a verlas desde el interior de una pecera: aguas gelatinosas me separaban más y más de ambas, sus voces me llegaban distantes, sus movimientos desaforados, y una tenue y

35 Bellatin, M., La escuela del dolor humano de Sechuán, México, Editorial Alfaguara, 2005, p. 433. 
feliz inconsciencia me reconcentraba sólo en el golpeteo de mi sangre como si de nuevo estuviera en el vientre seguro y cálido de una madre. Era sin duda una madre poderosa: una fortaleza de ladrillo que a su vez era el cuerpo dócil de una muñeca. ${ }^{36}$

Ana Clavel, a través de la contradicción semántica, de la combinación de polos opuestos, consigue crear un efecto de extrañeza, de conciliación de emociones opuestas:

Y sin embargo, algunas veces me he asomado. Entonces el corazón desbocado en un galope sin freno, que llega hasta el borde y luego no le queda sino saltar al vacío irremediable: un latido en expansión que no conoce límites, ni vergüenza, ni dolor. Justo ahí la vida, la muerte, los principios, el bien y el mal se anulan y uno no es más que el pequeño universo colapsado, el fuego oscuro, el color implosivo de la pasión que lo desborda. 37

Bellatin, en cuanto a él, juega con su propio cuerpo y con los mecanismos de la castración. Así pues, El Gran vidrio (2007) de Bellatin nos presenta la castración simbólica con un juego visual y semántico entre el voyerismo/exhibicionismo de sus órganos: "Lo único que parece escapar a este deterioro son mis testículos, siempre dispuestos para la exhibición"38.

La castración es el tema de predilección del psicoanálisis que produce ese efecto de Inquiètante étrangété o Unheimliche (1919):

Colocándose en un punto de vista racional, podría tratarse de negar que el temor por los ojos esté relacionado con la angustia de castración: se encontrará entonces perfectamente comprensible que un órgano tan precioso como el ojo sea protegido con una ansiedad correspondiente, ya hasta se podrá afirmar que tampoco tras la angustia de castración se esconde ningún secreto profundo, ninguna significación distinta de la mutilación en sí. 39

Para el psicoanálisis, solo la mirada puede simbolizar la angustia de la castración: "La mirada no se nos presenta más que bajo la forma de una extraña contingencia simbólica de lo que encontramos en el horizonte y como tope; a saber, la carencia constitutiva de la angustia de la castración" 40.

Todos esos miembros desarticulados, desmembrados, nos remiten finalmente en el universo de Bellatin al imaginario del fantasma, y no a la figura del propio autor

\footnotetext{
36 Clavel 2007, op. cit. (nota 8) p. 107.

37 Ibidem p.36.

38 Bellatin 2007, op.cit. (nota 11) p. 13.

39 Freud 1919 op.cit. (nota 29) p. 7.

40 Lacan 1964, op.cit. (nota 1) p. 85.
} 
y su miembro protésico. En Ana Clavel y Las Violetas son las flores del deseo (2007), los mecanismos de la mirada escópica nos permiten recrear una imagen que puede sugerir un erotismo, o bien alcanzado o, simplemente, un voyerismo soñado al que accede un lector ideal, quien reconstruye esa idea a la que invita una mirada narrada desde la pulsión:

Ya se aproxima mi hada. Mi ninfa del bosque. Mi amazona. Mi sacerdotisa. Su aroma dulce y cruel remonta las oquedades del sueño. Por un momento - pero muy breve, lo confieso-, la he confundido con la Desnombrada al escucharme murmurar que por fin ha de sembrarme en el vientre un nombre y un rostro verdaderos. Sus ojos son hipnóticos: espirales de éxtasis congelado. Su deseo frontal empuña ahora el filo luminoso de su propia alborada. No será eterna esta noche. ${ }^{41}$

\section{Conclusiones: "leer reconstruyendo"}

En El proceso creativo (1957), Duchamp señalaba la importancia del espectador en toda creación artística, quién consagra a la obra un sentido de posteridad. El artista busca una serie de reacciones en el espectador, las cuales no tienen por qué ser conscientes, pero que conformarían lo que Duchamp llama "el coeficiente del arte", es decir, el resultado entre lo que pretende expresar el artista y lo que realmente consigue transmitir al espectador:

El artista no es el único a realizar el acto de la creación porque el espectador establece el contacto entre la obra y el mundo exterior al descifrar e interpretar sus cualificaciones profundas y a partir de ahí, añade su propia contribución al proceso creativo. Esta contribución es incluso más evidente cuando la posteridad pronuncia su veredicto definido y rehabilitado de artistas olvidados ${ }^{42}$.

Esto es corroborado por Jean Michel Rey, quien afirma que la obra, en el sentido estético, debe ser un concepto abierto, que abra el paso a vías inéditas, originales. La modernidad es rica contrastes, en giros de diferente índole, que hacen que sea aún más absurdo querer definir "la forma", tanto para el que interpreta como para el que crea. No existe una perspectiva única, un conjunto de significaciones que correspondan a un movimiento determinado de escritura que se pueda enseñar o aprender como en un manual:

Es mi hipótesis -hay que alegar por un uso flotante, indeterminado de la palabra

41 Clavel 2007, op. cit. (nota 8) p.135.

42 Duchamp, M., Le processus créatif Poche, Paris, Editions L’Echoppe, 1987. La traducción es nuestra. 
"forma". Sin concebir este flote como negativo, como un obstáculo a superar Todo lo contrario. Si aceptamos reconocer tal indeterminación- de hecho y derecho-sin miedo a querer reducirla, el conjunto puede tomar otro giro. En una palabra: este flote, desde mi punto de vista, puede dar lugar a análisis inéditos, permitir movimientos de pensamiento que no tendrían probablemente lugar de existir si un concepto fuese definido y estabilizado, suscitaría incluso interrogantes de algún modo atípicos, abrir así vías fecundas. 43

En ese sentido, las pretensiones de Mario Bellatin sobre su estilo de escritura nos hacen pensar en las consideraciones de Duchamp sobre la obra del arte contemporáneo. Bellatin afirma en un juego de palabras: "Me siento escritor cuando voy desescribiendo". Y formula que los elementos narrativos tienen una función segunda en su literatura. Lo que intenta hacer con su escritura es un gesto de destrucción de la construcción narrativa. Para el escritor mexicano, lo que cuenta es precisamente ese lenguaje que no está escrito, aquello que le sugiere al lector la idea:

"Lo raro es ser un escritor raro", en donde trato vislumbrar lo que es "escribir sin escribir". De lo que soy consciente y siempre lo he sido es "escribir desescribiendo", que es otra categoría más (ya parece un trabalenguas): el hecho de yo ser un escritor es como responder a este impulso de la escritura. Pero después hay un proceso que es cuando me siento realmente escritor, cuando voy desescribiendo. En ese primer momento de escritura es cuando surge una serie de elementos que, curiosamente, para mí no son importantes y para el común de la gente -y por eso es que hay tantos malos libros- es lo fundamental de la literatura, como la imaginación desbordada, la cantidad de personajes complejos, el lenguaje poético. Toda esa parte la tengo que borrar, porque para mí es más importante lo no dicho que lo dicho. 44

Nos parece pertinente mencionar, para concluir este trabajo, la concepción del arte propuesta por Ortega y Gasset en La deshumanización del arte (1925) al referirse al arte vanguardista. Ortega concibe la vanguardia como arte para el cual lo único que cuenta es la idea y la intención del artista, es decir, el arte como manifestación que va más allá de la simple representación. Se trata entonces de una manifestación artística para una minoría, a contra corriente con el arte tradicional, el cual representaba el mundo tal y como había sido percibido por el órgano de la vista, al cual cualquiera podía identificarse. Por el contrario, el arte contemporáneo sólo se interesa a las ideas: pretende ir más allá de la representación, al concentrarse sobre lo que se esconde a la mirada. En este sentido, a fin de poder apreciar este tipo de

\footnotetext{
43 Michel-Rey, J., La forme en jeu, Paris, Presses universitaires de Vincennes Saint Denis, 1998, p. 102.

44 Bellatin, M., "Me siento escritor cuando voy desescribiendo", http://www.uasb.edu.ec/web/spondylus/contenido?mario-bellatin-34me-siento-escritor-cuando-voy-desescribiendo-34, 2014.
} 
arte, el espectador debe ir más allá de las imágenes, sabiendo que éstas no son más que un juego.

Cerramos nuestro artículo con una citación de Lacan acerca del campo escópico y el poder de la mirada en el espectáculo del mundo y de las cosas:

En nuestra relación con las cosas tal como es constituida por la vía de la visión y ordenada en las figuras de la representación, algo se transmite de piso en piso para estar siempre en ella en algún grado elidido -eso es lo que se llama la mirada. ${ }^{45}$

45 Lacan 1964, op.cit. (nota 1) p.85. 